\title{
PATHOMORPHOSIS OF EXTRAPULMONARY TUBERCULOSIS IN CHILDREN
}

\author{
Lidia Mykolyshyn \\ Department of tuberculosis and pulmonology \\ Danylo Halytsky Lviv National Medical University \\ 69 Pekarska str., Lviv, Ukraine, 79010 \\ piskyrandri@ukr.net \\ Zoriana Piskur \\ Department of tuberculosis and pulmonology \\ Danylo Halytsky Lviv National Medical University \\ 69 Pekarska str., Lviv, Ukraine, 79010 \\ piskyrandri@ukr.net
}

\begin{abstract}
Aim. To study clinical and epidemiological aspects of pathomorphosis of extrapulmonary tuberculosis clinical forms.

Materials and Methods. Retrospective analysis of 138 case histories in children aged to 15 years, obtaining extrapulmonary tuberculosis treatment in a specialized children's hospital during 1988-2015 was carried out. Among them, in 103 children, clinical forms of extrapulmonary tuberculosis combined with respiratory tuberculosis and in 35 children independent forms of extrapulmonary tuberculosis were found. Studied stage (1988-2015) was divided into 3 periods: I - 1988-1997, II - 1998-2007, III - 2008-2015.

During 2008-2015, in comparison to previous periods, the number of cases of peripheral lymph node tuberculosis (PLN), meninges and central nervous system tuberculosis, bones and joints tuberculosis, and ocular tuberculosis decreased. In 2008-2015, the share of combined forms of meninges and central nervous system tuberculosis and ocular tuberculosis remained at 1998-2007 level. During 2008-2015, skin tuberculosis was not diagnosed. Nevertheless, in 2008-2015, in 6.8 $\pm 10.2 \%$ of cases extrapulmonary tuberculosis combined with miliary tuberculosis, and in $5.8 \pm 10.4 \%$ of cases the process characterized by lethal outcome, moreover $4.9 \pm 10.7 \%$ from them - in recent years. It is important that during period I, in $19.6 \pm 13.2 \%$ of cases extrapulmonary tuberculosis combined with respiratory tuberculosis in reverse development phases, during period II - in $12.9 \pm 19.3 \%$ of cases, during period III - in $23.8 \pm 21.2 \%$ of cases.

Conclusion. Despite the reduction, extrapulmonary tuberculosis combined with severe forms of respiratory tuberculosis, which led to lethal outcome in children in $5.8 \pm 10.4 \%$ of cases. Tuberculosis epidemiological situation worsening, reversion of severe forms of tuberculosis with the development of extrapulmonary one and several organs injuries in children shows the necessity of social, preventive and therapeutic measures intensification among children.
\end{abstract}

Keywords: pathomorphosis, extrapulmonary tuberculosis, children.

\section{Introduction}

A significant increase in morbidity and mortality in 90-s changed the tuberculosis epidemiological situation. In this case, unlike raised respiratory tuberculosis morbidity, extrapulmonary tuberculosis morbidity increased slightly [1]. Nevertheless, some scientists point to the growth of extrapulmonary tuberculosis and a significant increase of patients with extrapulmonary tuberculosis hospitalization $[2,3]$. Besides, the share of extrapulmonary tuberculosis in developed countries is between 1/4 (Austria, Switzerland, Germany) to 1/3 (US, Iran), and even 1/2 (Canada) of all identified patients [4].

Some scholars point to delayed identification of extrapulmonary tuberculosis [5], other - to difficulties in its diagnosis, which leads to late detection [6].

Peculiarities of national accounting systems are also worth mentioning. In some countries, including Ukraine, pleural and intrathoracic lymph node (ITLN) tuberculosis are considered as extrapulmonary tuberculosis [7].

It should be noted, that issues of extrapulmonary tuberculosis in adults are often highlighted in literature; publications on this issue inchildren are insignificant and inconsistent. Some scientists pay attention, that despite the growth of morbidity among children, extrapulmonary tuberculosis 
remains stable, some of them point to extrapulmonary tuberculosis indicators increasing [6], and other point to their decreasing [7]. This fact raises interest and stimulates the study of clinical and epidemiological aspects of pathomorphosis of extrapulmonary tuberculosis in children.

\section{Aim}

To study clinical and epidemiological aspects of pathomorphosis of extrapulmonary tuberculosis clinical forms during 1988-2015.

\section{Materials and Methods}

Retrospective analysis of 138 case histories in children aged to 15 years, obtaining extrapulmonary tuberculosis treatment in a specialized children's hospital during 1988-2015 was carried out. Among them, in 103 children, clinical forms of extrapulmonary tuberculosis combined with respiratory tuberculosis and in 35 children independent forms of extrapulmonary tuberculosis were found.

Children with tuberculosis outside the chest organs lesions were classified as extrapulmonary tuberculosis. Combinations of extrapulmonary tuberculosis local forms and respiratory tuberculosis were considered as combined forms of extrapulmonary tuberculosis. Independent forms of extrapulmonary tuberculosis were such extrapulmonary tuberculosis local forms, which didn't show any specific features of respiratory organs lesions after X-Ray detection. Clinical forms of pleural and ITLN tuberculosis were classified as respiratory tuberculosis.

To research clinical and epidemiological aspects of pathomorphosis of extrapulmonary tuberculosis clinical forms, the studied stage (1988-2015) was divided into 3 periods (the first - 1988-1997; the second - 1998-2007; the third - 2008-2015). Changes in structure of extrapulmonary tuberculosis clinical forms and both combined and independent forms during studied periods were considered as pathomorphosis.

According to the case histories data, following information was analyzed: extrapulmonary tuberculosis clinical forms, respiratory tuberculosis clinical forms, combined clinical forms of extrapulmonary tuberculosis with respiratory tuberculosis, the number of affected organs.

All material of our research was statistically analyzed. To determine significant difference of selected options share, in percentage, Fisher formula was used [8]. In particular, the arithmetic mean $(\mathrm{M})$, the average error $(\mathrm{m})$, the probability index $(\mathrm{t})$ and the probability difference $(\mathrm{P})$ were determined by Student's table [9].

\section{Results of Research}

Among 1886 children treated from tuberculosis local forms in specialized children's hospital during 1988-2015, the share of extrapulmonary tuberculosis was $7.3 \pm 2.2 \%$ (138).

The structure of extrapulmonary tuberculosis in children is shown on Fig. 1.

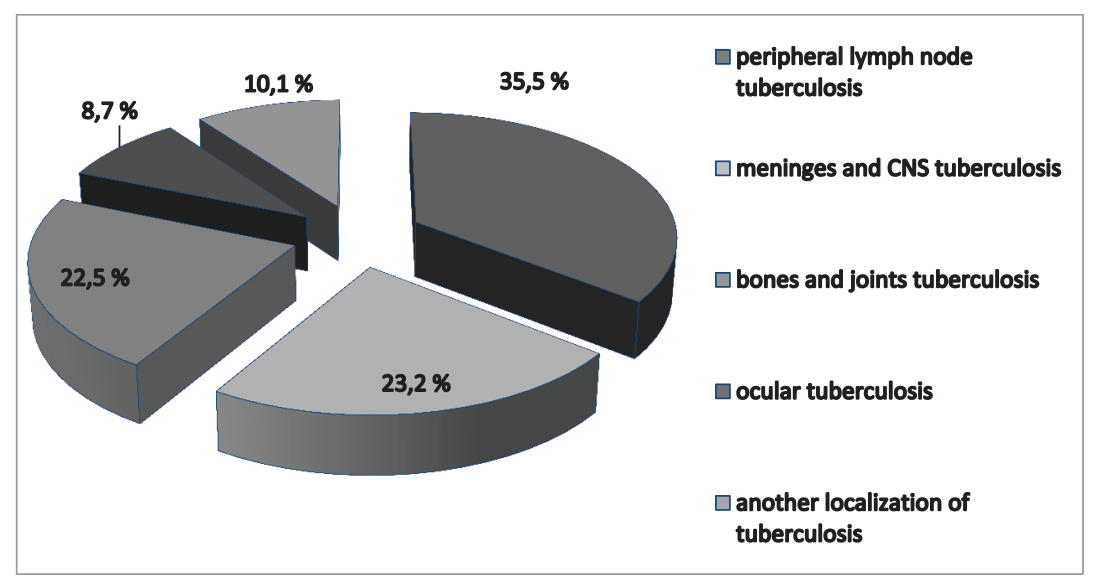

Fig. 1. The structure of extrapulmonary tuberculosis in children 
In the structure of extrapulmonary tuberculosis, the share of peripheral lymph node tuberculosis (PLN) was 35.5 $\pm 6.8 \%-49$, meninges and central nervous system (CNS) tuber-

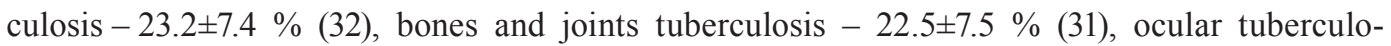
sis $-8.7 \pm 8.5 \%$ (12), another localization of tuberculosis $-10.1 \pm 8.3 \%$ (14). In structure of clinical forms of extrapulmonary tuberculosis of another localization, the shares of abdominal and renal tuberculosis were the same $(2.9 \pm 9.6 \%-4)$; the shares of skin and spleen tuberculosis were also the same $(2.2 \pm 10.4 \%-3)$.

The distribution of extrapulmonary tuberculosis clinical forms during different periods is shown in Table 1.

\section{Table 1}

The distribution of extrapulmonary tuberculosis clinical forms during different periods (abs./\%)

\begin{tabular}{|c|c|c|c|c|}
\hline \multirow[b]{2}{*}{ Extrapulmonary tuberculosis clinical forms } & \multicolumn{3}{|c|}{ Periods } & \multirow[b]{2}{*}{$\mathbf{P}$} \\
\hline & $\begin{array}{c}\text { I } \\
(1988-1997) \\
\text { abs. }\end{array}$ & $\begin{array}{c}\text { II } \\
(1998-2007) \\
\text { abs. }\end{array}$ & $\begin{array}{c}\text { III } \\
(2008-2015) \\
\text { abs. }\end{array}$ & \\
\hline Peripheral lymph node tuberculosis & $\begin{array}{c}27 \\
55,1 \pm 9,7^{*}\end{array}$ & $\begin{array}{c}13 \\
26,6 \pm 12,7\end{array}$ & $\begin{array}{c}9 \\
18,3 \pm 13,6^{*}\end{array}$ & $\begin{array}{l}{ }^{*}<0,05 \\
>0,05\end{array}$ \\
\hline Meninges and CNS tuberculosis & $\begin{array}{c}14 \\
43,8 \pm 13,7\end{array}$ & $\begin{array}{c}10 \\
31,2 \pm 15,4\end{array}$ & $\begin{array}{c}8 \\
25,0 \pm 16,3\end{array}$ & $>0,05$ \\
\hline Bones and joints tuberculosis & $\begin{array}{c}13 \\
41,9 \pm 14,2\end{array}$ & $\begin{array}{c}12 \\
38,7 \pm 14,6\end{array}$ & $\begin{array}{c}6 \\
19,4 \pm 17,6\end{array}$ & $>0,05$ \\
\hline Ocular tuberculosis & $\begin{array}{c}8 \\
66,7 \pm 17,8\end{array}$ & $\begin{array}{c}3 \\
25,0 \pm 30,6\end{array}$ & $\begin{array}{c}1 \\
8,3\end{array}$ & $>0,05$ \\
\hline Another localization of tuberculosis & $\begin{array}{c}5 \\
35,7 \pm 13,3\end{array}$ & $\begin{array}{c}4 \\
28,6 \pm 26,0\end{array}$ & $\begin{array}{c}5 \\
35,7 \pm 13,3\end{array}$ & $>0,05$ \\
\hline Total & $\begin{array}{c}67 \\
48,6 \pm 6,1^{*}\end{array}$ & $\begin{array}{c}42 \\
30,4 \pm 7,0\end{array}$ & $\begin{array}{c}29 \\
21,0 \pm 7,6^{*}\end{array}$ & $\begin{array}{l}{ }^{*}<0,05 \\
>0,05\end{array}$ \\
\hline
\end{tabular}

Note: * - the difference is reliable as to specific weight of extrapulmonary tuberculosis and tuberculosis of peripheral lymph nodes in III period comparing with I one

As it is shown in Table 1, the share of extrapulmonary tuberculosis in period III was significantly less, than in period I $(21.0 \pm 7.6 \%$ to $48.6 \pm 6.1 \%$; $<0.05)$ and slightly less than in period II (21.0 $\pm 7.6 \%$ to $30.4 \pm 7.0 \% ; \mathrm{p}>0.05)$. Regarding extrapulmonary tuberculosis clinical forms, the share of PLN tuberculosis in period III, comparing to period I, was significantly lower $(18.3 \pm 13.6 \%$ to $55.1 \pm 9.7 \% ; \mathrm{p}<0.05)$. The shares of meninges and CNS tuberculosis $(25.0 \pm 16.3 \%$ to $43.8 \pm 13.7 \%$; $\mathrm{p}>0.05)$, bones and joints tuberculosis $(19.4 \pm 17.6 \%$ to $41.9 \pm 14.2 \% ; \mathrm{p}>0.05)$, ocular tuberculosis ( $8.3 \%$ to $66.7 \pm 17.8 \% ; \mathrm{p}>0.05$ ) slightly decreased, and only the share of another localization of tuberculosis $(35.7 \pm 13.3 \%$ to $35.7 \pm 13.3 \%$; $>0.05)$ remained on the level of period $\mathrm{I}$.

The distribution of combined and independent forms of extrapulmonary tuberculosis during different periods is shown in Table 2.

\section{Table 2}

The distribution of combined and independent forms of extrapulmonary tuberculosis during different periods (abs. $/ \%)$

\begin{tabular}{|c|c|c|c|c|}
\hline Extrapulmonary tuberculosis forms & $\begin{array}{c}\text { I } \\
(1988-1997) \\
\text { abs. }\end{array}$ & $\begin{array}{c}\text { Periods } \\
\text { II } \\
(\mathbf{1 9 9 8 - 2 0 0 7 )} \\
\text { abs. }\end{array}$ & $\begin{array}{c}\text { III } \\
(2008-2015) \\
\text { abs. }\end{array}$ & $\mathbf{P}$ \\
\hline Combined $(n=103)$ & $\begin{array}{c}51 \\
49,5 \pm 7,0\end{array}$ & $\begin{array}{c}31 \\
30,1 \pm 8,2\end{array}$ & $\begin{array}{c}21 \\
20,4 \pm 9,0\end{array}$ & $>0,05$ \\
\hline Independent $(\mathrm{n}=35)$ & $\begin{array}{c}16 \\
45,7 \pm 12,9\end{array}$ & $\begin{array}{c}11 \\
31,4 \pm 14,7\end{array}$ & $\begin{array}{c}8 \\
22,9 \pm 15,9\end{array}$ & $>0,05$ \\
\hline
\end{tabular}


As it is shown in Table 2, the highest share of both combined $(49.5 \pm 7.0 \%-51)$ and independent $(45.7 \pm 12.9 \%-16)$ forms was in period I, the lowest - in period III $(20.4 \pm 9.0 \%-21$ and $22.9 \pm 15.9 \%-8$, respectively).

The distribution of combined and independent forms of PLN tuberculosis during different periods is shown on Fig. 2.

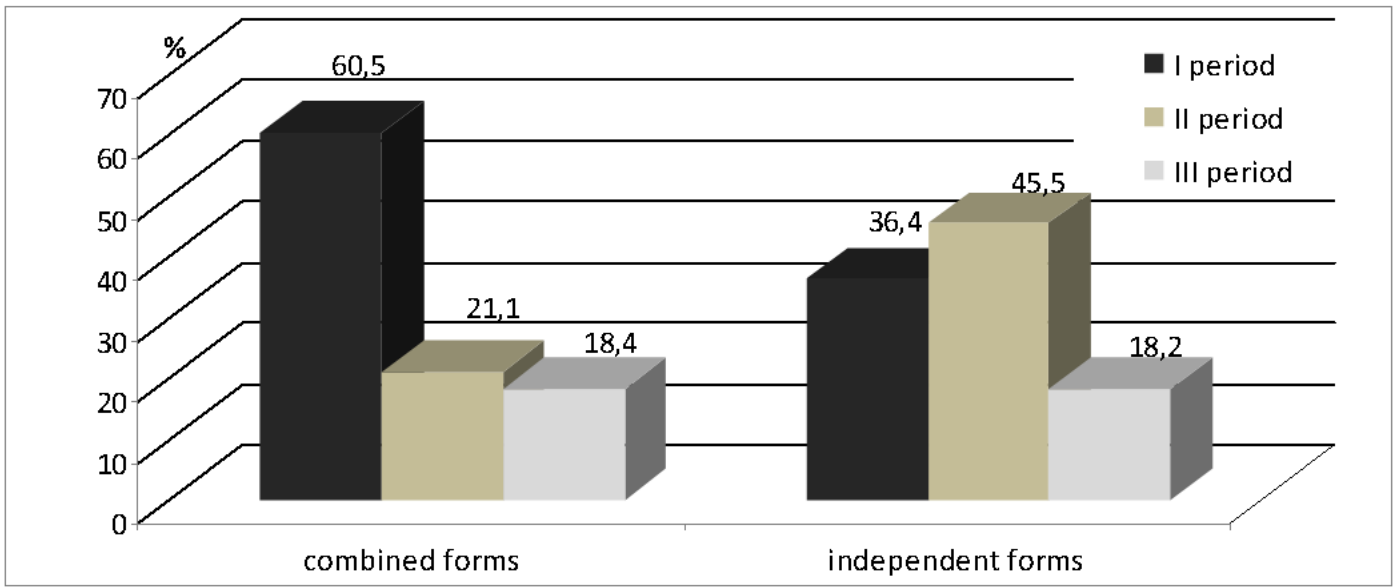

Fig. 2. The distribution of combined and independent forms of PLN tuberculosis during different periods

As it is shown on Fig. 2, the highest share $(60.5 \pm 10.4 \%-23)$ of combined forms of PLN tuberculosis is in period I, the lowest $(18.4 \pm 15.8 \%-7)$ is in period III. Independent forms were detected mostly in period II $-45.5 \pm 24.8 \%$ (5), and the least in period III $-18.2 \pm 13.6 \%$ (9).

The distribution of combined and independent forms of meninges and CNS tuberculosis during different periods is shown on Fig. 3.

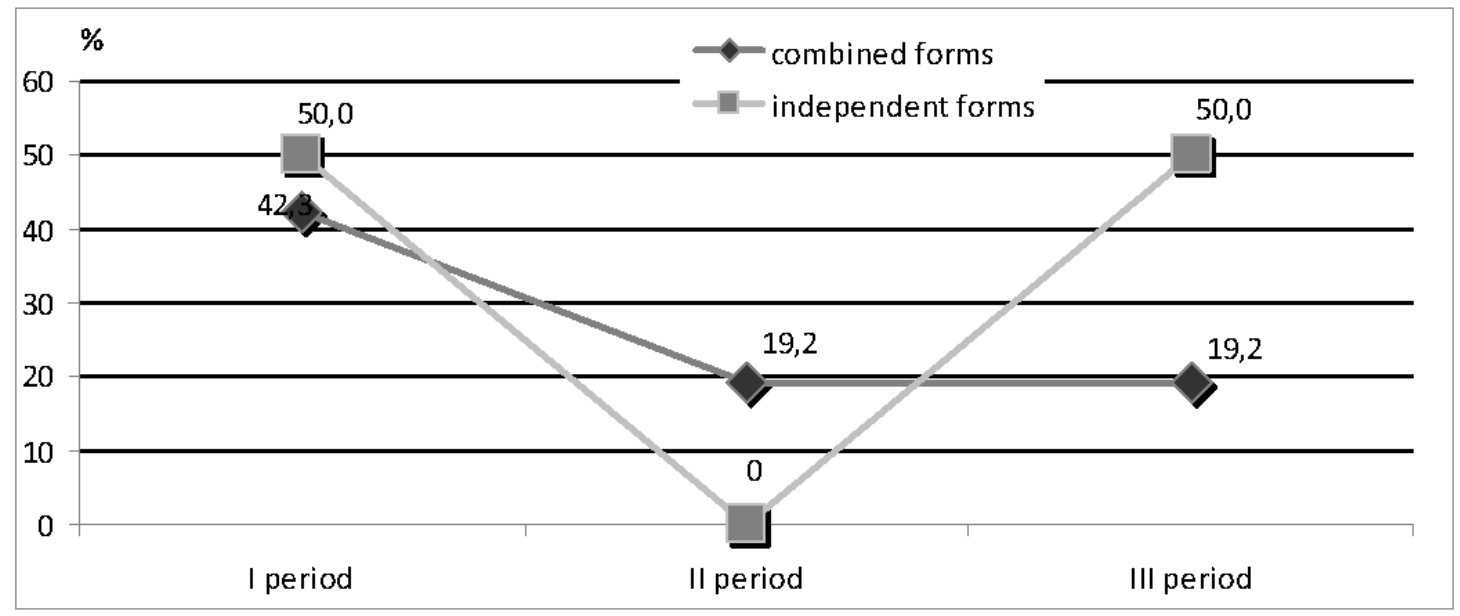

Fig. 3. The distribution of combined and independent forms of meninges and CNS tuberculosis during different periods

As it is shown on Fig. 3, the highest share $(42.3 \pm 15.6 \%-11)$ of combined forms of meninges and CNS tuberculosis was in period I, but in periods II and III it was the same $(19.2 \pm 19.6 \%-5)$. Independent forms in periods I and III had the same ratios $(50.0 \pm 35.3 \%-3)$, and were not observed in period II.

The distribution of combined and independent forms of bones and joints tuberculosis during different periods is shown on Fig. 4. 
As it is shown on Fig. 4, the share of combined forms of bones and joints tuberculosis was almost the same $(38.9 \pm 19.9 \%-7$ and $44.4 \pm 18.7 \%-8)$ in periods I and II, and it was the lowest in period III $(16.7 \pm 26.3 \%-3)$. The share of independent forms was the highest in period I $(46.2 \pm 22.2 \%-6)$ and the lowest in period III $(23.1 \pm 29.8 \%-3)$.

The distribution of combined and independent forms of ocular tuberculosis during different periods is shown on Fig. $\mathbf{5}$.

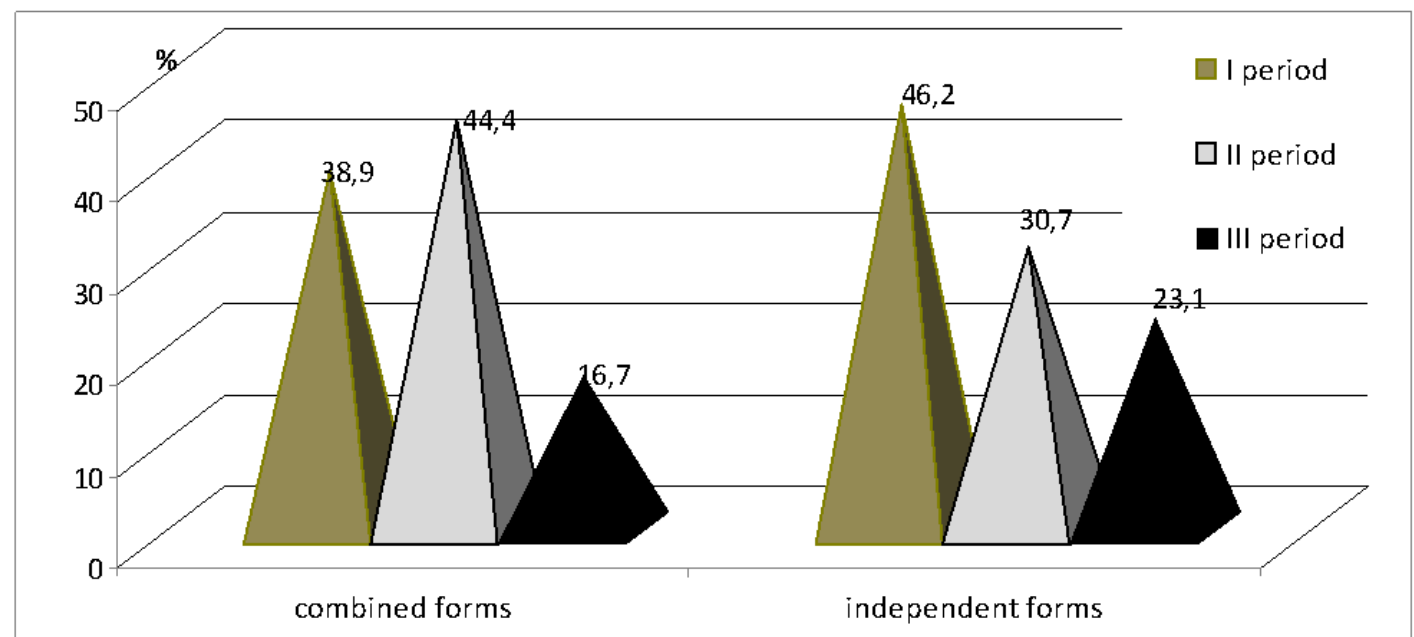

Fig. 4. The distribution of combined and independent forms of bones and joints tuberculosis during different periods

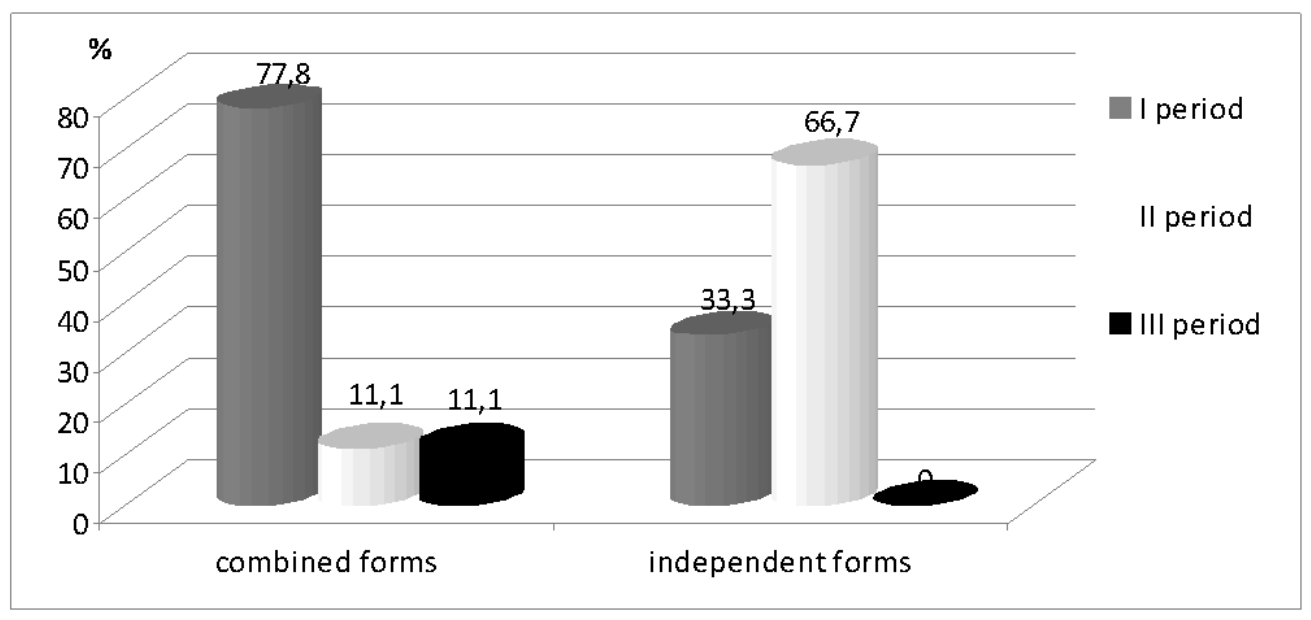

Fig. 5. The distribution of combined and independent forms of ocular tuberculosis during different periods

As it is shown on Fig. 5, most often combined forms of ocular tuberculosis were identified in period I $(77.8 \pm 16.9 \%-7)$, in periods II and III their share was in the same ratio (to $11.1 \%-1)$. Independent forms were frequently identified in period II $(66.7 \pm 47.1 \%-2)$, and were not identified in period III.

The distribution of combined and independent forms of extrapulmonary tuberculosis of another localization during different periods is shown on Fig. 6.

The share of combined forms of another localization of tuberculosis was the highest in period III $(41.7 \pm 24.6 \%-5)$, the lowest - in period I $(25.0 \pm 30.6 \%-3)$. Independent forms were observed only in period I. 


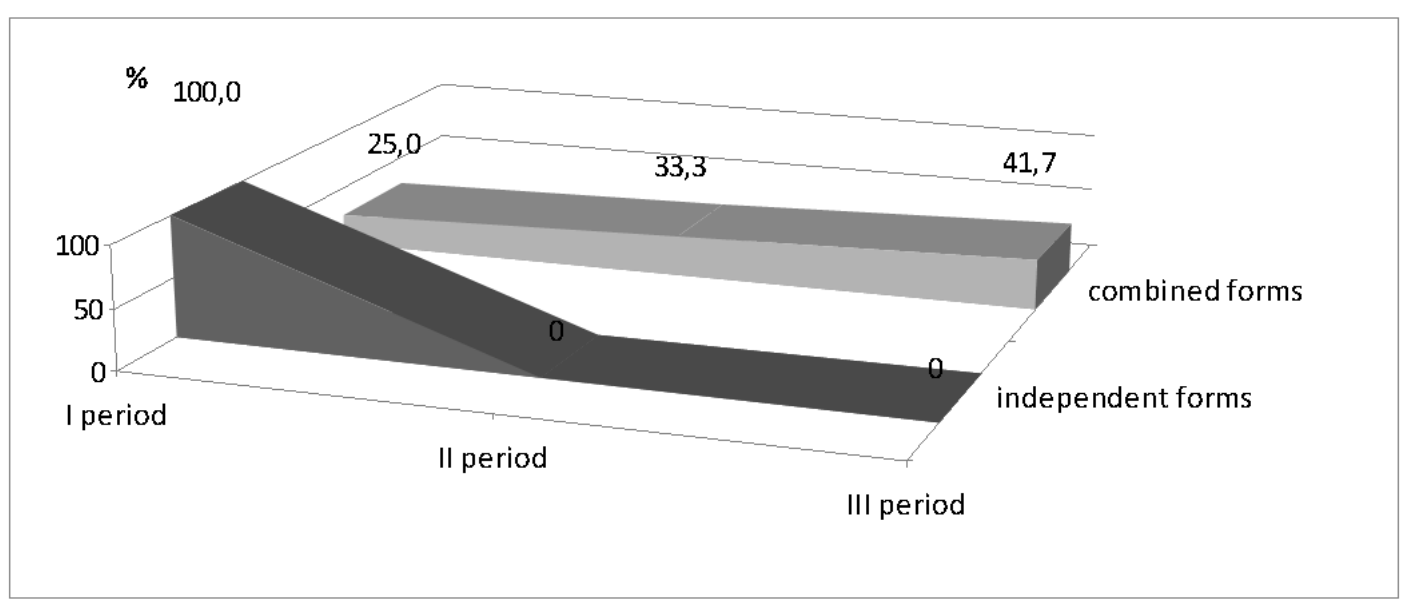

Fig. 6. The distribution of combined and independent forms of extrapulmonary tuberculosis of another localization during different periods

\section{Discussion of Results of Research}

According to our data, among children suffering from local forms of tuberculosis, the share of extrapulmonary tuberculosis is $7.3 \pm 2.2 \%$, which coincides with Russian researchers' data [10]. According to the data of other scientists, the share of extrapulmonary tuberculosis is 17.9-23.7-28.1\% [11, 12]. In accordance to our data, in the structure of extrapulmonary tuberculosis PLN tuberculosis prevails and is $35.5 \pm 6.8 \%$. A significant number of scientists believe that PLN tuberculosis occupies the leading position among extrapulmonary tuberculosis and is $20.0-31.2 \%$ among all extrapulmonary forms $[6,13]$. Some scientists think that among extrapulmonary tuberculosis PLN tuberculosis is the most widespread [4, 14-17], and it is often the only manifestation of extrapulmonary tuberculosis in the USA [18].

According to some authors' data, the most frequent (66.7 \%) localization among extrapulmonary tuberculosis is bones and joints tuberculosis, especially in preschool age [19]. Some scientists believe that children are more predisposed to PLN tuberculosis development, as well as meninges and CNS tuberculosis, than to bones and joints tuberculosis [20, 21]. According to our data, the share of bones and joints tuberculosis is $22.5 \pm 7.5 \%$, and this disease ranks third in extrapulmonary tuberculosis structure; the share of meninges and CNS tuberculosis is $23.2 \pm 7.4 \%$, and this disease ranks second. The number of scholars still considers tubercular meningitis to be a severe disease [22-25].

According to our data, the share of ocular tuberculosis is $8.7 \pm 8.5 \%$, which is different from the other scientists' data $-1.9-2.8 \%$ [26]. Regarding other localizations of extrapulmonary tuberculosis, they are being seldom diagnosed in children and in literature mostly shown in adults.

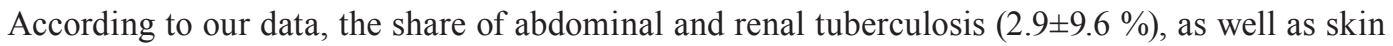
and spleen tuberculosis $(2.2 \pm 10.4 \%)$, was the same.

Therefore, according to our data, during 2008-2015, comparing to 1988-1997, the share of PLN tuberculosis, meninges and CNS tuberculosis, bones and joints tuberculosis, and ocular tuberculosis became lower, and only the share of tuberculosis of another localization remained on the 1988-1997 level. According to our data, combined forms of extrapulmonary tuberculosis, have the share of $74.6 \pm 4.2 \%$. During 2008-2015, comparing to 1988-1997, their share became slightly lower. Nevertheless, the share of combined forms of meninges and CNS tuberculosis, as well as ocular tuberculosis, in 2008-2015 remained on the 1998-2007 level.

However, during 2008-2015, a severe form of disease was identified in four children suffering from PLN, miliary tuberculosis was diagnosed in three of them, and tubercular meningoencephalitis in one child. Two early children (one with tubercular meningoencephalitis, and the other 
with miliary tuberculosis) died. Besides, despite the fact that during 2008-2015, in comparison to 1988-1997, the share of combined forms of meninges and CNS tuberculosis became lower, the mentioned disease characterized by lethal outcome in three cases.

It's worth mentioning, that despite the fact that the number of cases of bones and joints tuberculosis became lower in 2008-2015, in child aged 1 year and 2 months suffering from hip joint tuberculosis combined with bilateral lesions of ITLN, meninges, eyes and cervical lymph nodes, disease characterized by lethal outcome.

The frequency of combined forms of ocular tuberculosis was the same in 1998-2007 and in 2008-2015, but it was slightly lower comparing 1988-1997. During 2008-2015, only combined forms of ocular tuberculosis were identified.

Combined forms of another localization of tuberculosis were diagnosed in all periods; the highest their quantity was in 2008-2015; their independent forms occurred only in 1988-1997. Skin tuberculosis was not observed during 2008-2015. Besides, such clinical forms of extrapulmonary tuberculosis, as abdominal and renal tuberculosis in 2008-2015 combined with other organs lesions, including miliary tuberculosis.

It's important that during 1988-1997 extrapulmonary tuberculosis in $19.6 \pm 13.2 \%$ of cases combined with respiratory tuberculosis in reverse development phases; during 1998-2007 - in $12.9 \pm 19.3 \%$ of cases, during $2008-2015$ - in $23.8 \pm 21.2 \%$ of cases, which indicates the late detection of respiratory tuberculosis and then led to extrapulmonary tuberculosis development.

Therefore, in recent 30 years extrapulmonary tuberculosis in children had clinical and epidemiological pathomorphosis, which manifested in its significant decrease and a slight reduction in its clinical and combined forms. However, combined forms of meninges and CNS tuberculosis, as well as ocular tuberculosis, during 2008-2015 remained on the 1998-2007 level, and skin tuberculosis was not diagnosed. Nevertheless, extrapulmonary tuberculosis in $6.8 \pm 10.2 \%$ of cases combined with miliary tuberculosis, and in $5.8 \pm 10.4 \%$ of cases the disease characterized by lethal outcome, moreover, $4.9 \pm 10.7 \%$ of them happened in the last years. Recently, extrapulmonary tuberculosis combined with respiratory tuberculosis in reverse development phases more often than in previous years. It point to the late detection of respiratory tuberculosis, which led to extrapulmonary tuberculosis forms development. The mentioned above shows tuberculosis epidemiological situation worsening, reversion of severe forms of tuberculosis with the development of extrapulmonary one and several organs lesions in children, and the necessity of social, preventive and therapeutic measures among children.

\section{Conclusion}

1. Among children, suffering from local forms of tuberculosis, the share of extrapulmonary tuberculosis is $7.3 \pm 2.2 \%$.

2. In recent 30 years, extrapulmonary tuberculosis in children had clinical and epidemiological pathomorphosis, which manifested in its significant decrease $(21.0 \pm 7.6 \%$ to $48.6 \pm 6.1 \%$; $\mathrm{p}<0.05$ ) and a slight reduction in its clinical and combined forms.

3. Despite the decrease, extrapulmonary tuberculosis combined with severe forms of respiratory tuberculosis, which in $5.8 \pm 10.4 \%$ of cases led to children death.

4. Tuberculosis epidemiological situation worsening, reversion of severe forms of tuberculosis with the development of extrapulmonary one and several organs lesions in children, and the necessity of social, preventive and therapeutic measures among chldren.

\section{References}

[1] Aksenova, V. A., Baryshnikova, L. A., Sevost'yanova, T. A., Klevno, N. I. (2014). Tuberkulez u detei v Rossii i zadachi ftiziatricheskoi i obshchei pediatricheskoi sluzhby po profilaktike i rannemu vyyavleniyu zabolevaniya. Tuberkulez i bolezni legkikh, 3, 40-46.

[2] Peto, H. M., Pratt, R. H., Harrington, T. A., LoBue, P. A., Armstrong, L. R. (2009). Epidemiology of Extrapulmonary Tuberculosis in the United States, 1993-2006. Clinical Infectious Diseases, 49 (9), 1350-1357. doi: 10.1086/605559 
[3] Kul'chavenya, E. V. (2008). Kontrol' vnelegochnogo tuberkuleza v Sibiri i na Dal'nem Vostoke. Problemy tuberkuleza i boleznei legkikh, 9, 16-19.

[4] Baghaie, N., Khalilzade, S., Boloursaz, M. R., Khodayari, A. ., Velayati, A. A. (2010). Extrapulmonary tuberculosis in children: two years study. Acta Medica Iranica, 48 (4), 239-243.

[5] Punga, V. V., Skachkova, E. I., Yakimova, M. A., Erokhin, V. V. (2006). Dinamika vozrastno-polovoi struktury zabolevaemosti tuberkulezom za 10 let v territoriyakh Rossiiskoi Federatsii, kuriruemykh GU TsNIIT RAMN. Problemy tuberkuleza i bolezni legkikh, 7, 16-20.

[6] Chebotareva, A. A., Chebotareva, T. V., Oblogina, L. I., Kosinova, A. M., Permyakova, V. M. (2008). Metody vyyavleniya i klinicheskaya kharakteristika vnelegochnogo tuberkuleza u detei iz grupp riska. Problemy tuberkuleza i boleznei legkikh, 4, 11-17.

[7] Bilogortseva, O. I. (2013). Epidemichna situatsiya shchodo tuberkul'ozu u ditei ta pokazniki protituberkul'oznoi roboti sered dityachogo naselennya v Ukraini u 2012 r. Ukrains'kii pul'monologichnii zhurnal, 3, 66-70.

[8] Urbakh, V. Yu. (1975). Statisticheskii analiz v biologicheskikh i meditsinskikh issledovaniyakh. Moscow: Meditsina, 295.

[9] Mintser, O. P., Ugarov, B. N., Vlasov, V. V. (1991). Metody obrabotki meditsinskoi informatsii. Kyiv: Vishcha shkola, 271.

[10] Filippov, A. V., Ovsyankina, E. S., Denisova, L. S., Stakheeva, L. B. (2008). Sravnitel'nyi analiz zabolevaemosti tuberkulezom detei i podrostkov v Moskve i Penzenskoi oblasti. Problemy tuberkuleza i boleznei legkikh, 1, 6-10.

[11] Mikhailova, Yu. V., Son, I. M., Skachkova, E. I., Strelikov, S. N. (2009). Rasprostranenie tuberkuleza sredi detei i podrostkov v Rossitsiskoi Federatsii (analiz dannykh ofitsial'noi statistiki). Problemy tuberkuleza i boleznei legkikh, 1, 5-10.

[12] Tuberculosis annual report 2010-(3) childhood tuberculosis (2012). Kekkaku, 87 (8), 549-553.

[13] Makarova, U. E. (2008). Lazeroterapiya v kompleksnom lechenii bol'nykh v rannei stadii tuberkuleza perifericheskikh limfaticheskikh uzlov. Problemy tuberkuleza i boleznei legkikh, 6, 15-18.

[14] Swaminathan, S., Rekha, B. (2010). Pediatric Tuberculosis: Global Overview and Challenges. Clinical Infectious Diseases, 50 (s3), S184-S194. doi: 10.1086/651490

[15] Verma, P., Jain, A., Patra, S. K., Gandhi, S., Sherwal, B. L., Chaudhary, M. (2010). Evaluation of polymerase chain reaction (PCR) using hupB gene in diagnosis of tuberculous lymphadenitis in fine needle aspirates. Indian J. Tuberculosis, 57, 128-133.

[16] Hatwal, D., Chaudhari, S., Joshi, A. K., Rathaur, V. K. (2013). Patterns of extrapulmonary tuberculosis in children: a hospital based study. Indian J. of Community Health, 25 (1), 22-27.

[17] Shubha, A. B., Sapna, H., Dinesh Rao, B. (2010). Tuberculosis lymphadenitis presenting a diagnostic dilemma - a case report. International J. of Dental clinics, 2 (2), 48-52.

[18] Fontanilla, J.-M., Barnes, A., von Reyn, C. F. (2011). Current Diagnosis and Management of Peripheral Tuberculous Lymphadenitis. Clinical Infectious Diseases, 53 (6), 555-562. doi: 10.1093/cid/cir454

[19] Bilogortseva, O. I., Feshchenko, Yu. I. (2011). Epidemiologichna situatsiya shchodo tuberkul'ozu u ditei ta pokazniki protituberkul'oznoi roboti sered dityachogo naselennya v Ukraini u 2010 rotsi. Ukrains'kii pul'monologichnii zhurnal, 4, 11-15.

[20] Forssbohm, M., Zwahlen, M., Loddenkemper, R., Rieder, H. L. (2008). Demographic characteristics of patients with extrapulmonary tuberculosis in Germany. European Respiratory Journal, 31 (1), 99-105. doi: 10.1183/09031936.00020607

[21] Tinsa, F., Essaddam, L., Fitouri, Z., Nouira, F., Douira, W. et. al. (2009). Extra-pulmonary tuberculosis in children: a study of 41 cases. La tunisie Medicale, 87 (10), 693-698. 
[22] Buonsenso, D., Serranti, D., Valentini, P. (2010). Management of central nervous system tuberculosis in children: light and shade. European Review for Medical and Pharmacological Sciences, 14 (10), $845-853$

[23] Subinay, M., Kumar, D. A., Kumar, M. S. (2013). Tuberculous meningitis in children: a two years experience in a peripheral medical college of India. International journal of medical and applied sciences, 2, 34-46.

[24] Christensen, A.-S. H., Andersen, Å. B., Thomsen, V. Ø., Andersen, P. H., Johansen, I. S. (2011). Tuberculous meningitis in Denmark: a review of 50 cases. BMC Infectious Diseases, 11 (1). doi: 10.1186/14712334-11-47

[25] Principi, N., Esposito, S. (2012). Diagnosis and therapy of tuberculous meningitis in children. Tuberculosis, 92 (5), 377-383. doi: 10.1016/j.tube.2012.05.011

[26] Nechaeva, O. B., Burylova, E. A. (2009). Epidemicheskaya situatsiya po tuberkulezu glaz v Sverdlovskoi oblasti. Problemy tuberkuleza i boleznei legkikh, 7, 14-19. 